\title{
CD4.CD8 ratio decrease in AIDS, explained by a molecular mimicry between African HIV-1 Nef and Notch-1. Nef as a target for vaccine and NF-Kb inhibitors (salicylate, resveratrol,curcumin, epigallocatechine-3-gallate)
}

\author{
Guy MK Tran ${ }^{1,2^{*}}$, Adrien Caprani², Laurent Gerbaud
}

From 17th International Symposium on HIV and Emerging Infectious Diseases (ISHEID) Marseille, France. 23-25 May 2012

\section{Background}

The AIDS hallmark is the simultaneous fall in CD4 and rise in CD8 $\mathrm{T}$ lymphocytes. Interestingly, this very pathognomonic but unexplained decrease of CD4/CD8 ratio is also characteristic of a member of the EGF family, Notch1 function (Fowlkes BJ, 2002). Calenda V (1994) found that Nef hampered drastically bone marrow progenitors cells functionality. African HIV-1 strain NDK (Spire B, 1989), which induced a fulminant AIDS killing the patient in only 15 days, decreases dramatically CD4 counts. Nef is the most abundant HIV-1 protein in infected cells $(85 \%$ of mRNA). Nef is a superantigen, its action is amplified 10,000 times compared to a common antigen.

\section{Objective}

We found previously Notch-1 in the LTR (Long Terminal Repeat) of another retrovirus [Mouse Mammary Tumor Virus (MMTV)] (Tran MKG, Eurocancer, Paris, 1999). As Nef is located also in HIV-1 LTR, we looked for Notch-1 in Nef.

\section{Methods}

Amino Acid (AA) alignment between Epidermal Growth Factor (EGF) family members (including Notch-1) and Nef (Los Alamos HIV sequences Database, 2002).

\footnotetext{
* Correspondence: positifpresident@yahoo.fr

'Clermont-Ferrand University, Hospital Hotel-Dieu, Public Health, ClermontFerrand, France

Full list of author information is available at the end of the article
}

\section{Results}

Nef COOH-terminus of HIV-1 clade D African strains (from Congo Democratic Republic, Chad, Tanzania, Uganda, South Africa, Kenya,...), but not from other parts of the world (other non-D clades), was a perfect molecular mimetic of Notch-1: They shared a heptapeptide (7 AA) SRLAFEH. The homology between Nef (Poon AFY, 2009) and Notch (BLASTP on mouse Notch-1) chimera was 67 AA long with 4 His, 1 Cys and 1 Trp (highly significant): Nef : GWCFEVEEDTEGETNSLLHPISQHGMEDPERQVLVWRFNSRLAFEHKARLMHPEFYKNC Notch : GWLLD...FEQDSEG ETNSLPHLISQHAL ANPEMQALA-HGKSRLAFEH QVRLSHLPVANNC It included the Nef LL and ED doublets precisely implicated in CD4 down-regulation and $E E$ in $\beta$-COP recruitement(Benichou S.1994).

\section{Conclusions}

This opens new avenues for a vaccine targeted to NefNotch specific to Africa, a continent devastated by AIDS and tuberculosis (in South Africa, about 60\% HIV-1 infected patients had also tuberculosis).

\section{Author details \\ 'Clermont-Ferrand University, Hospital Hotel-Dieu, Public Health, Clermont- Ferrand, France. ${ }^{2}$ Association POSITIFS, Paris cedex 18 , France.}

Published: 25 May 2012 
doi:10.1186/1742-4690-9-S1-P24

Cite this article as: Tran et al:: CD4.CD8 ratio decrease in AIDS, explained by a molecular mimicry between African HIV-1 Nef and Notch-1. Nef as a target for vaccine and NF-Kb inhibitors (salicylate, resveratrol,curcumin, epigallocatechine-3-gallate). Retrovirology 20129 (Suppl 1):P24.

Submit your next manuscript to BioMed Central and take full advantage of:

- Convenient online submission

- Thorough peer review

- No space constraints or color figure charges

- Immediate publication on acceptance

- Inclusion in PubMed, CAS, Scopus and Google Scholar

- Research which is freely available for redistribution

Submit your manuscript at www.biomedcentral.com/submit
Ciomed Central 